\title{
REVIEW OF PROBLEMATIC THRESHOLD VALUES FOR QUALITY OF SECONDARY FUELS FROM WASTE AND PROPOSAL FOR THEIR CHANGE
}

\author{
Juraj Musil 1,2, Emília Hroncová ${ }^{3, \star}$ and Juraj Ladomerský ${ }^{3}$ \\ 1 INECO Ltd., Mladých budovatel'ov 2, 97411 Banská Bystrica, Slovakia \\ ${ }^{2}$ Department of Environmental Management, Faculty of Natural Science, Matej Bel University, Tajovského 40, 97401 Banská Bystrica, \\ Slovakia \\ ${ }^{3}$ European Science and Research Institute, Hlinku 29, 96001 Zvolen, Slovakia
}

Article Info:

Received:

11 December 2018

Revised:

4 March 2019

Accepted:

5 March 2019

Available online:

31 March 2019

Keywords:

Waste

Secondary fuels

Pyrolysis

Gasification

Problematic parameters

\begin{abstract}
From 2015 onwards, the parameters of the end-of-waste status for refuse-derived fuels have been defined in Slovak legislation. These parameters were adopted in view of the increasing number of pyrolysis and gasification technologies producing liquid and gaseous energy carriers from different types of waste. The present paper addresses the appropriateness and adequacy of the exiting quality standards for the production and use of alternative secondary fuel, in the form in which they are currently in effect in Slovak environmental legislation, as well as the ability of the existing pyrolysis process to comply with those standards. With respect to the issue of the appropriateness and adequacy of the exiting quality standards, we propose new threshold values for parameters that have been proposed inappropriately as well as for undefined parameters. Regarding the ability of the existing pyrolysis process to comply with effective quality standards for alternative secondary fuel from waste, we present a comparison of the values of parameters available from the existing and upcoming pyrolysis-type facilities with the threshold values defined in the first part of the paper and identification of the most problematic parameters (those where the actual values most often exceed the threshold values defined in the first part of the paper). The final section of the paper deals with the results of testing runs of a pyrolysis facility using real RDF waste (with relatively high $\mathrm{Cl}$ content) and the important implications of these results for the issue of gaseous secondary fuels produced from waste.
\end{abstract}

\section{INTRODUCTION}

For the purposes of this paper, the abbreviation ATT (alternative thermal treatment) is used to designate methods and devices based exclusively on substoichiometric processes (in relation to the amount of oxygen supplied) in the form of pyrolysis or gasification.

Technologies based on the principles of thermal treatment of waste are currently highly debated. The estimate of the number of facilities currently operated world-wide is 2200 , with a processing capacity of about 280 million tonnes of waste per year. More than 250 facilities of this type were built from 2010-2014, and existing estimates anticipate the construction of more than 500 new facilities with a capacity of about 150 million tonnes of waste per year by 2024 (Hroncová, Ladomerský, \& Musil, 2016).

The dominant type of these facilities is based on conventional combustion with the hyperstoichiometric oxygen added to the process. Besides this established method for waste treatment, waste pyrolysis and waste gasification are offered on the market as additional thermal treatment processes. These processes - also called "alternative" thermal treatment - have been on the market since the 1970s, offered by changing providers under different labels (Quicker, Neuerburg, Noël, \& Huras, 2015).

One of the key areas of the permitting procedures, which also significantly influences the technological feasibility of ATT facilities in Slovakia, is the air protection legislation and within it, the legislation regulating the so-called secondary fuels made from waste.

This paper addresses the following research issues:

- The appropriateness and adequacy of the existing quality standards for the production and use of alternative secondary fuel in the form in which they are currently in effect in Slovak environmental legislation;

- The ability of the existing pyrolysis process to comply
* Corresponding author

Emília Hroncová

email: emilia.hroncova@gmail.com
Detritus / Volume 05 - 2019 / pages 163-171

https://doi.org/10.31025/2611-4135/2019.13799

(c) 2018 Cisa Publisher. Open access article under CC BY-NC-ND license 
with those standards.

The following results are included in this paper:

- Proposal of the parameters that were proposed inappropriately;

- Comparison of the values of parameters available from the existing and future pyrolysis-type facilities with the threshold values defined in the first part of the paper and identification of the most problematic parameters (those where the actual values most often exceed the threshold values defined in the first part of the paper). The final part of the paper deals with the results of testing runs of a pyrolysis facility using real RFD-type waste (with relatively high $\mathrm{Cl}$ content) and the important implications of these results for the issue of gaseous secondary fuels produced from waste.

\section{CURRENT LEGISLATIVE FRAMEWORK - OVERVIEW OF THRESHOLD VALUES}

Due to the fact that in the Slovak Republic, practically all operating ATT technologies are focused on the production of liquid and/or gaseous secondary fuels from waste used in the subsequent phase for the production of energy in some form of combustion process, the requirements for the quality and purity of these fractions are key factors influencing the impact of their subsequent combustion on environmental pollution.

Decree No 228/2014 of the Ministry of the Environment of the Slovak Republic (Ministry of the environment of the Slovak Republic, 2014) laid down new quality standards for waste-derived fuels and provides for precise criteria for the end-of-waste status of these fuels, with an emphasis on air protection. One of the main reasons for the adoption of these end-of-waste criteria was the matter of the complian- ce of existing ATTs in Slovakia with relevant environmental obligations, notably in respect of compliance with emission limits for combustion gases from these fuels. The above decree was primarily intended to respond to this unfavourable situation.

\subsection{Quality requirements for liquid secondary fuels}

To achieve the end-of-waste status for liquid fuels produced from waste by pyrolysis facilities, they must comply with established legislative requirements expressed as the threshold values of the pollutant content referred to in 2, Part I, Annex no. 3 of the Decree No 228/2014 (Table 1). These threshold values are in fact quality requirements before the actual combustion of such fuel (i.e. they do not pertain to the exhaust gases after combustion of the fuel).

\subsection{Quality requirements for gaseous secondary fuels}

In order to achieve end-of-waste status for gaseous fuels produced from waste by pyrolysis facilities which are used as a source of heat for the pyrolysis process, they must comply with the statutory requirements expressed as the threshold values of the pollutant content defined in Point 3, Part I of Annex 3 to Decree No 228/2014 (Table 2). As with liquid fuel, these threshold values are in fact quality requirements before the actual combustion of such fuel (i.e. they do not pertain to the exhaust gases after combustion of the fuel).

\subsection{The importance of threshold values}

Taking into account the requirements laid down under Decree No 228/2014, the operators of these existing devices have two possible modes of operation to choose from:

TABLE 1: Requirements for solid secondary fuels or liquid secondary fuels (threshold values) - existing and proposed values (Ministry of the environment of the Slovak Republic, 2014).

\begin{tabular}{|c|c|c|c|c|c|c|}
\hline \multicolumn{3}{|c|}{ Pollutant } & \multicolumn{2}{|c|}{$\begin{array}{l}\text { Existing threshold values for pollutant content } \\
\qquad\left[\mathrm{mg}^{\mathrm{M}} \cdot \mathrm{MJ}^{-1}\right]^{1)}\end{array}$} & \multicolumn{2}{|c|}{$\begin{array}{l}\text { Proposed threshold values for pollutant content } \\
\qquad\left[\mathrm{mg}^{\mathrm{M}} \mathrm{MJ}^{-1}\right]^{1)}\end{array}$} \\
\hline & & & Median & 80th percentile & Median & 80th percentile \\
\hline \multicolumn{3}{|c|}{$\mathrm{Sb}$} & $\leq 0.5$ & $\leq 0.75$ & $\leq 0.5$ & $\leq 0.75$ \\
\hline \multicolumn{3}{|c|}{ As } & $\leq 0.8$ & $\leq 1.2$ & $\leq 0.8$ & $\leq 1.2$ \\
\hline \multicolumn{3}{|c|}{$\mathrm{Pb}$} & $\leq 4$ & $\leq 6$ & $\leq 4$ & $\leq 6$ \\
\hline \multicolumn{3}{|c|}{$\mathrm{Cd}$} & $\leq 0.05$ & $\leq 0.075$ & $\leq 0.05$ & $\leq 0.075$ \\
\hline \multicolumn{3}{|c|}{$\mathrm{Cr}$} & $\leq 1.4$ & $\leq 2.1$ & $\leq 1.4$ & $\leq 2.1$ \\
\hline \multicolumn{3}{|c|}{ Co } & $\leq 0.7$ & $\leq 1.05$ & $\leq 0.7$ & $\leq 1.05$ \\
\hline \multicolumn{3}{|c|}{$\mathrm{Ni}$} & $\leq 1.6$ & $\leq 2.4$ & $\leq 1.6$ & $\leq 2.4$ \\
\hline \multicolumn{3}{|c|}{$\mathrm{Hg}$} & $\leq 0.02$ & $\leq 0.03$ & $\leq 0.02$ & $\leq 0.03$ \\
\hline \multicolumn{3}{|c|}{ Polycyclic hydrocarbons (PAHs) } & $\leq 1.5$ & $\leq 2.5$ & \multicolumn{2}{|c|}{$\leq 8 \%$ wt. } \\
\hline $\mathrm{Cl}$ & \multicolumn{2}{|c|}{$\begin{array}{l}\text { Secondary Fuels except } \\
\text { Regenerated Heating Oil }\end{array}$} & $\leq 100$ & $\leq 100$ & $\leq 100$ & $\leq 100$ \\
\hline \multirow{3}{*}{$S$} & \multirow{3}{*}{$\begin{array}{l}\text { Liquid } \\
\text { Secondary } \\
\text { Fuels }\end{array}$} & Class A & & & \multicolumn{2}{|c|}{$<0.1 \mathrm{wt} \%$} \\
\hline & & Class B & \multicolumn{2}{|c|}{$\geq 0.1 \% a<1 w t \%$} & \multicolumn{2}{|c|}{$\geq 0.1 \% a<1 w t \%$} \\
\hline & & Class $\mathrm{C}^{2)}$ & \multicolumn{2}{|c|}{$\geq 1 \% a<3 w t \%$} & \multicolumn{2}{|c|}{$\geq 1 \% a<3 w t \%$} \\
\hline
\end{tabular}

1) Threshold values are related to the calorific value of the secondary fuel produced

2) The fuel concerned has limited use in accordance with $\S 6(2)$ of Decree No 228/2014 
TABLE 2: Requirements in accordance with Annex 3a, Part I of Decree No 228/2014 for gaseous secondary fuels (threshold values) - existing and proposed values (Ministry of the environment of the Slovak Republic, 2014).

\begin{tabular}{|c|c|c|}
\hline Pollutant & $\begin{array}{l}\text { Existing threshold values for pollutant content } \\
\qquad\left[\mathrm{mg}^{\left.-\mathrm{m}^{-3}\right]^{1)}}\right.\end{array}$ & $\begin{array}{l}\text { Proposed threshold values for pollutant content } \\
\qquad\left[\mathrm{mg}^{\left.-\mathrm{m}^{-3}\right]^{1)}}\right.\end{array}$ \\
\hline Particles / Aerosols & Analysis ${ }^{2)}$ & Technically free from \\
\hline Total sulfur & $\leq 10$ & $\leq 10$ \\
\hline Hydrogen sulfide $\left(\mathrm{H}_{2} \mathrm{~S}\right)$ & $\leq 5$ & $\leq 5$ \\
\hline Carbonyl sulfide (COS) & $\leq 5$ & $\leq 5$ \\
\hline Compounds of chlorine expressed as $\mathrm{HCl}$ & $\leq 1$ & $\leq 1$ \\
\hline Compounds of fluorine expressed as HF & $\leq 1$ & $\leq 1$ \\
\hline $\mathrm{Hg}$ and its compounds & $\leq 0.05$ & $\leq 0.05$ \\
\hline $\mathrm{Cd}+\mathrm{Tl}$ and their compounds & $\leq 0.05$ & $\leq 0.05$ \\
\hline Other metals and their compounds & Analysis $^{2)}$ & $\leq 0.05$ \\
\hline Persistent Organic Compounds (POPs) & Analysis ${ }^{2)}$ & $\leq 0.1 \mathrm{ng} \mathrm{TEQ} / \mathrm{m}^{3}$ \\
\hline
\end{tabular}

1) Standard state conditions: temperature $0^{\circ} \mathrm{C}$, pressure $101.3 \mathrm{kPa}$

2) If the measurement result is $\leq L O D$, state methodology and threshold of determination (LOD); technical standards for analysis of gas purity for heating gases, technical gases, technical standards for air analysis in the working environment or eligible emission measurement methodologies in accordance with $\S 20(13)$ of the Air Act (No 137/2010)

- The facility produces fuel from the waste that achieves

end-of-waste status. The use of such fuel in the subsequent combustion process is subject to the same environmental requirements as is the use of standard fuel (in particular with regard to the established emission limits applied to such an incinerator);

- The facility produces "fuel" that does not reach the endof-waste status. Such an output "product" retains its waste status and its subsequent use in the combustion process is subject to the same requirements as is the combustion of waste in waste incinerators.

Requirements imposed on ATT facilities by Decree No $228 / 2014$ have a special position within the environmental legislative framework of the Slovak Republic for the following reasons:

- Compliance or noncompliance with these requirements has a direct impact on the intensity of negative environmental impact of individual ATT facilities;

- Requirements are directly linked to the inherent technological capabilities of individual ATT technologies and thus serve as good indicators of their overall technical quality and long-term sustainability;

- Following the previous point, failure to meet these requirements implies the pressing need for significant technological change and improvements of the technology in question.

\subsection{Liquid secondary fuels from waste - inadequa- tely proposed threshold value}

According to Decree No 228/2014, the threshold value for the maximum permitted content of polycyclic aromatic compounds (diaromatics, triaromatics and higher aromatics) in liquid secondary fuel is $1.5 \mathrm{mg}^{\mathrm{M}} \mathrm{MJ}^{-1}$ (for median) and $2.5 \mathrm{mg}^{\mathrm{MJ}} \mathrm{MJ}^{-1}$ (for 80th percentile).

However, the same threshold value applicable to standard diesel motor fuel is $8 \%$ wt., a limit that is more than 1000 times less strict (taking into account the fact that the heating value of "standard" pyrolysis oil from waste is very similar to the heating value of standard diesel motor fuel, as shown in the heating values in Table 5).

Since practically every liquid secondary fuel from waste produced in Slovakia is intentionally produced and modified by the operators in order to approximate its properties to the properties of diesel motor fuel, it could be argued that the threshold value of the parameter PAH is not adequate and should be modified to a level that will take into account the real nature of the liquid secondary fuel produced (in particular its close relationship with conventional diesel-based fuels).

\subsection{Gaseous secondary fuels from waste - undefi- ned parameters}

Whereas the end-of-waste parameters for liquid secondary fuels have defined threshold values in full, the three end-of-waste parameters for gaseous secondary fuels are defined in Table 3.

It is not clear from the above formulation whether LOD (as defined in Note 2 below the table) is considered to be the threshold. For the parameter "Other metals and their compounds" it is not even explicitly clear to what extent this parameter should be determined (i.e. which metals and their compounds should be determined) or whether it is a group form of determination (and if so, which groups exactly). The explanatory memorandum to the legislation indicates that for the determination of these parameters, producers should consult the standards and methods referred to in Note 2 below the table (in the order in which they are given).

However, it is important to note that none of the standards and methods mentioned in this note contain specific numerical values of any of these end-of-waste parameters, which could be used as threshold values. Consequently, the threshold values for these three end-ofwaste parameters are practically undefined in the current legal definition. 


\section{RESULTS AND DISCUSSION}

\subsection{Proposal of undefined threshold values and cor- rection of inadequate threshold value}

With regard to the origin of Decree No 228/2014, we can take into account that this legislation was largely inspired by Austria's ordinance on waste incineration, No 389/2002 (Bundesministers für Land- und Forstwirtschaft, Umwelt und Wasserwirtschaft und des Bundesministers für Wirtschaft, 2002). The threshold values stated in this ordinance could be used as a guideline for the undefined and inadequate threshold values in the Slovak standard.

According to this ordinance, waste incineration requirements do not apply to pyrolysis gas and waste gas that is cleaned to the extent that subsequent burning does not cause emissions higher than natural gas combustion. Specific parameters defining this degree of purity are given in annex 10 to the ordinance. However, only the threshold values for total sulfur, hydrogen sulfide and carbon dioxide sulfide are explicitly stated in this annex, which further states that the total content of solids, halogen components and ammonia is subject to the same requirements as those for natural gas within the meaning of the standard ÖVGW Richtline G 31 "Natural gas in Austria".

In the ÖVGW Richtline G 31 standard, the "Particle and Aerosol" parameter has a threshold value stated as "technisch frei", which means that natural gas should not contain any detectable impurities of these constituents.

Considering that the Slovak standard for natural gas quality has a threshold value for the same parameter stated as "absent" (with virtually the same meaning as "technically free from" as in ÖVGW Richtline G 31), it is logical to propose a threshold value for the "Particle/Aerosol" parameter for gaseous secondary fuels as "Technically free from" (meaning that the threshold value is the LOD of the appropriate determination method).

In view of the fact that the Austrian ordinance does not give threshold values for metals and persistent organic compounds, and taking into account that the parameters " $\mathrm{Hg}$ and its compounds" and " $\mathrm{Cd}+\mathrm{Tl}$ and their compounds" in Slovak Decree No 228/2014 are set at the levels corresponding to the emission limits for waste incineration (within the meaning of Annex No. 5 of Decree

TABLE 3: Parameters defining the end-of-waste status for gaseous secondary fuels with explicitly undefined threshold values (MoE SR Decree No 228/2014) (Ministry of the environment of the Slovak Republic, 2014).

\begin{tabular}{l|c} 
Pollutant & $\begin{array}{c}\text { Threshold values for pollutant } \\
\text { content }\left[\mathbf{m g} \cdot \mathbf{m}^{-3} \text { ] }\right.\end{array}$ \\
\hline Particles / Aerosols & analysis ${ }^{1)}$ \\
\hline Other metals and their compounds & analysis ${ }^{1)}$ \\
\hline $\begin{array}{l}\text { Persistent Organic Compounds } \\
\text { (POPs) }\end{array}$ & analysis ${ }^{1)}$ \\
\hline
\end{tabular}

1) If the measurement result is $\leq L O D$, state methodology and threshold of determination (LOD); technical standards for analysis of gas purity of heating gases or technical gases, technical standards for air analysis in the working (indoor) environment and air quality or approved emission measurement methodologies in accordance with $\S 20(13)$ of the Air Act (No 137/2010)
No 410/2012), the threshold values for these parameters could be proposed as follows:

- The extent of determination of the parameters "Persistent organic compounds" and "Other metals and their compounds" could be identical to the extent of determination for these parameters according to section III.1 of annex 5 to Decree No 410/2012;

- The actual threshold values for both parameters ("Other metals and their compounds" and "Persistent organic compounds") could be identical to the emission limits stated for the parameters "Other heavy metals" and "PCDD + PCDF" in section III. 1 of annex 5 to Decree No $410 / 2012$.

Having regard to these facts, the requirements for gaseous secondary fuels (threshold values) should then be set as stated in the second part of Table 2.

For liquid secondary fuels, we propose adjusting the limit for PAU content so that the new value reflects a qualitative similarity to standard diesel fuel as well as the same use of such fuels, i.e. at the same level as is the existing value for standard diesel fuel (second part of Table 1).

\subsection{Identification of most problematic parameters}

This section provides an overview of all available analyses, demonstrating compliance with liquid and gaseous secondary fuels quality requirements, for existing as well as for some future ATT technologies in the Slovak Republic. We identify problematic parameters (i.e. parameters that are correctly defined, have a limit value set at an appropriate level, but are most frequently exceeded).

Table 4 provides available values of parameters defining the end-of-waste status for gaseous secondary fuels for selected future pyrolysis facilities in the Slovak Republic.

Table 5 provides available values of parameters defining the end-of-waste status for liquid secondary fuels for selected existing and future pyrolysis technologies in the Slovak Republic.

All the available values of liquid secondary fuel are stated as the values of one determination (and therefore, neither the median nor the 80th percentile is established for them).

All actual values exceeding the established threshold values are highlighted in bold. Given the fact that these are sensitive data, the data shown in all tables are anonymised (i.e. without specifying to which particular technology they apply).

\subsubsection{Problematic threshold values for gaseous secondary fuels}

From available analyses demonstrating the degree of compliance with the threshold values of gaseous secondary fuels, we can state that problems arise mainly in respect of the parameter "Compounds $\mathrm{Cl}$ expressed as $\mathrm{HCl}$ ".

In the case of one identified parameter overrun of the "Compounds F expressed as HF", it is highly probable that the test device was contaminated with the previously tested doses of waste since the tested feed material did not 
TABLE 4: Available values of end-of-waste status parameters for gaseous secondary fuels for selected future pyrolysis facilities (Musil, Hroncová, \& Ladomerský, 2017).

\begin{tabular}{|c|c|c|c|c|c|}
\hline Pollutant & $\begin{array}{c}\text { Threshold values } \\
\text { of pollutant } \\
\text { content [mg.m-3] }\end{array}$ & $\begin{array}{c}\text { Facility } 3 \\
\text { Analysis } 05 / 2015\end{array}$ & $\begin{array}{c}\text { Facility n3 } \\
\text { Analysis } 4 / 2017\end{array}$ & $\begin{array}{c}\text { Facility n4 } \\
\text { Analysis } 04 / 2017\end{array}$ & $\begin{array}{c}\text { Facility n4 } \\
\text { Analysis 04/2017 }\end{array}$ \\
\hline Particles/aerosols & Not determined & 1.30 & 1.90 & $<1.0$ & $<1.0$ \\
\hline Total sulfur & 10 & 8.70 & 7.06 & 70.27 & 6.73 \\
\hline Hydrogen sulfide $\left(\mathrm{H}_{2} \mathrm{~S}\right)$ & 5 & 2.30 & 1.41 & 9.00 & 0.63 \\
\hline Carbon dioxide sulfide (COS) & 5 & - & $<1$ & 100.07 & $<1.00$ \\
\hline Compounds of chlorine expressed as $\mathrm{HCl}$ & 1 & 140.86 & 351.84 & 536.91 & 122.21 \\
\hline Compounds of fluorine expressed as $\mathrm{HF}$ & 1 & - & 1.579 & 0.105 & 0.105 \\
\hline $\mathrm{Hg}$ and its compounds & 0.05 & - & $<0.001$ & $<0.001$ & $<0.001$ \\
\hline $\mathrm{Cd}+\mathrm{Tl}$ and their compounds & 0.05 & $0.01+<0.01$ & $<0.010+<0.010$ & $<0.01+<0.01$ & $<0.01+<0.01$ \\
\hline $\begin{array}{l}\text { Other metals and their compounds (Sb } \\
\mathrm{As}+\mathrm{Pb}+\mathrm{Cr}+\mathrm{Co}+\mathrm{Cu}+\mathrm{Mn}+\mathrm{Ni}+\mathrm{V})\end{array}$ & Not determined & - & $<$ LOD & $<$ LOD & $<$ LOD \\
\hline $\begin{array}{l}\text { Persistent Organic Compounds (POPs) } \\
\text { (PCDD + PCDF) }\end{array}$ & Not determined & - & $<0.008$ & - & - \\
\hline Input material & & RDF & $\begin{array}{c}\text { Waste plastic } \\
\text { (mixture HDPE+PP) }\end{array}$ & $\begin{array}{l}\text { Sterilised medical } \\
\text { waste }\end{array}$ & $\begin{array}{l}\text { Waste plastic } \\
\text { (mixture PE+PP) }\end{array}$ \\
\hline $\mathrm{Cl}$ content in input waste & & - & $0.053 w t \%$ & $0.6 w t \%$ & - \\
\hline
\end{tabular}

contain fluorine in a detectable amount.

The case of one identified overrun of the parameters "total sulphur" " $\mathrm{H}_{2} \mathrm{~S}$ " and "COS" concerns the specificity of tested hospital waste. The standard plastic waste from municipal waste (or plastic waste of related origin) does not present problems with the threshold values exceeding the above-mentioned parameters.

\section{Total $\mathrm{Cl}$ expressed as $\mathrm{HCl}$}

Because the vast majority of existing and future pyrolysis facilities in the Slovak Republic process or are contemplating the processing of waste plastics with a different degree of separation and purity, the presence of a significant amount of chlorine in the input waste will be the rule rather than the exception and is therefore a valid assumption.

In connection with the above, and given the fact that:

- in the pyrolysis process, most of the chlorine present in the plastic waste passes into the gas phase (predominantly as $\mathrm{HCl}$ )

- chlorine in gaseous secondary fuel increases the risk of presence of PCDD/PCDF-based pollutants in discharged flue gases and contributes to increased corrosive wear of used combustion plants

- the threshold value for this parameter is established to an extremely strict level according to the "Pollution at the natural gas level" principle

then the fulfilment of the threshold value of the parameter "Compounds $\mathrm{Cl}$ expressed as $\mathrm{HCl}$ " is one of the most important issues faced by pyrolysis plants in Slovakia since legislation governing the end-of-waste status of secondary fuels came into force.

From the data shown in Table 4, it is clear that (without exception) all available analyses of gaseous secondary fuels produced from plastic waste significantly exceed the established threshold value.

A very important fact, relevant for all the above-men- tioned tests, is the fact that none of the tested facilities are equipped with any form of standard device for removing acidic components (with emphasis on $\mathrm{HCl}$ ) in the gas produced.

Since the model of thermal decomposition of PVC (as the main precursor of $\mathrm{Cl}$ in the gas phase from the pyrolysis process) currently in use assumes that the $\mathrm{Cl}$ bonded in the PVC molecule is released exclusively in the form of gaseous $\mathrm{HCl}$, it is a valid assumption that the removal of such an inorganic $\mathrm{Cl}$ in the gas phase should be a relatively trouble-free matter.

Therefore, as an additional, final part of this paper, we present the experimental results of a test run of one of the currently developed and tested pyrolysis devices, retrofitted with an alkaline countercurrent absorber specifically aimed at removing $\mathrm{HCl}$ present in the gaseous secondary fuel being developed.

\subsubsection{Problematic threshold values for liquid secondary fuels}

Available analyses indicate that the following parameters are most likely problematic (i.e. there is the highest probability of exceeding the threshold value):

- Polycyclic hydrocarbons

- Total sulfur content expressed as wt\%.

\section{Polycyclic hydrocarbons}

The problem of exceeding the threshold value of the parameter "polycyclic hydrocarbons" is linked to an inappropriate definition of this value and is not a manifestation of the problematic quality of the produced liquid fuels.

\section{Total sulfur content}

This concerns a parameter where the threshold value for liquid secondary fuels from waste is defined in three classes (class $A$ with a total sulfur content below $0.1 \mathrm{wt} \%$, class B with a total sulfur content of $0.1 \mathrm{wt} \%$ to $1 \mathrm{wt} \%$, and 
TABLE 5: Available values of end-of-waste status parameters for liquid secondary fuels for selected existing and future pyrolysis facilities (Musil et al., 2017)

\begin{tabular}{|c|c|c|c|c|c|c|c|c|c|c|c|c|}
\hline \multirow{2}{*}{ Pollutant } & \multicolumn{2}{|c|}{$\begin{array}{l}\text { Threshold values of pollut- } \\
\text { ant content [mg/MJ] }\end{array}$} & \multirow{2}{*}{$\begin{array}{l}\text { Facility } 1 \\
\text { Analysis } \\
11 / 2014\end{array}$} & \multirow{2}{*}{$\begin{array}{l}\text { Facility } 1 \\
\text { Analysis } \\
03 / 2015\end{array}$} & \multirow{2}{*}{$\begin{array}{l}\text { Facility } 2 \\
\text { Analysis } \\
02 / 2016\end{array}$} & \multirow{2}{*}{$\begin{array}{l}\text { Facility } 3 \\
\text { Analysis } \\
05 / 2015\end{array}$} & \multirow{2}{*}{$\begin{array}{l}\text { Facility } 3 \\
\text { Analysis } \\
09 / 2015\end{array}$} & \multirow{2}{*}{$\begin{array}{l}\text { Facility } 3 \\
\text { Analysis } \\
10 / 2015\end{array}$} & \multirow{2}{*}{$\begin{array}{c}\text { Facility } 3 \\
\text { Analysis } \\
4 / 2017\end{array}$} & \multirow{2}{*}{$\begin{array}{l}\text { Facility } 4 \\
\text { Analysis } \\
02 / 2017\end{array}$} & \multirow{2}{*}{$\begin{array}{l}\text { Facility } 4 \\
\text { Analysis } \\
04 / 2017\end{array}$} & \multirow{2}{*}{$\begin{array}{l}\text { Facility } 5 \\
\text { Analysis } \\
02 / 2017\end{array}$} \\
\hline & Median & $\begin{array}{l}\text { 80th } \\
\text { percentile }\end{array}$ & & & & & & & & & & \\
\hline $\begin{array}{l}\text { Heating } \\
\text { value [MJ] }\end{array}$ & & & 38,06 & 43,96 & 41,61 & 40,38 & 42,72 & & 38,08 & 45,77 & 44,48 & 41,22 \\
\hline $\mathrm{Sb}$ & 0.5 & 0.75 & 0.0263 & 0.3997 & $<0.0120$ & $<0.2$ & - & - & $<0.1$ & $<0.1$ & $<0.1$ & $<0.012$ \\
\hline As & 0.8 & 1.2 & - & - & $<0.0240$ & $<0.05$ & - & - & $<0.05$ & $<0.05$ & $<0.05$ & $<0.0073$ \\
\hline $\mathrm{Pb}$ & 4 & 6 & 0.0525 & 0.0014 & $<0.0014$ & $<0.05$ & - & - & $<0.05$ & $<0.05$ & $<0.05$ & $<0.073$ \\
\hline $\mathrm{Cd}$ & 0.05 & 0.075 & 0.0158 & & $<0.0007$ & $<0.01$ & - & - & $<0.01$ & $<0.01$ & $<0.01$ & $<0.012$ \\
\hline $\mathrm{Cr}$ & 1.4 & 2.1 & 0.0788 & 0,0680 & $<0.0014$ & $<0.05$ & - & - & $<0.02$ & $<0.02$ & $<0.02$ & $<0,049$ \\
\hline Co & 0.7 & 1.05 & - & - & $<0.0014$ & $<0.05$ & - & - & $<0.05$ & 0.05 & 0.05 & $<0.073$ \\
\hline $\mathrm{Ni}$ & 1.6 & 2.4 & - & - & $<0.0014$ & $<0.1$ & - & - & $<0.08$ & $<0.08$ & $<0.08$ & $<0.12$ \\
\hline $\mathrm{Hg}$ & 0.02 & 0.03 & - & - & 0.0001 & $<0.03$ & - & - & $<0.01$ & $<0.01$ & $<0.01$ & 0.0003 \\
\hline $\begin{array}{l}\text { Polycyclic } \\
\text { hydrocar- } \\
\text { bons (PAH) }\end{array}$ & 1.5 & 2.5 & - & - & 528.73 & - & - & - & 20 & 29.28 & 19.51 & 3,202 \\
\hline $\mathrm{Cl}$ & 100 & 150 & 2.63 & $<2.27$ & 1.56 & 28 & $<1.42$ & - & 4 & 3.7 & $<1.0$ & 2.50 \\
\hline S & $\begin{aligned} & <0.1 \mathrm{wt} \% \\
\geq 0.1 \% \mathrm{a} & <1 \mathrm{wt} \% \\
\geq 1 \% \mathrm{a} & <3 \mathrm{wt} \%\end{aligned}$ & - & $\begin{array}{l}0.78 \\
w t \%\end{array}$ & $\begin{array}{l}0.42 \\
w t \%\end{array}$ & $\begin{array}{c}0.0054 \\
w t \%\end{array}$ & $\begin{array}{c}0.0003 \\
w t \%\end{array}$ & $\begin{array}{c}0.0061 \\
w t \%\end{array}$ & $\begin{array}{c}0.0012 \\
w t \%\end{array}$ & $\begin{array}{c}0.022 \\
w t \%\end{array}$ & $\begin{array}{l}0.014 \\
w t \%\end{array}$ & $\begin{array}{l}0.018 \\
w t \%\end{array}$ & $0.83 \%$ \\
\hline $\begin{array}{l}\text { Input } \\
\text { material }\end{array}$ & & & $\begin{array}{l}\text { Waste } \\
\text { tyres }\end{array}$ & $\begin{array}{l}\text { Waste } \\
\text { tyres }\end{array}$ & $\begin{array}{l}\text { Unspeci- } \\
\text { fied plastic } \\
\text { waste }\end{array}$ & RDF & $\begin{array}{l}\text { Unspeci- } \\
\text { fied plastic } \\
\text { waste }\end{array}$ & $\begin{array}{c}\text { Sterilised } \\
\text { hospital } \\
\text { waste }\end{array}$ & $\begin{array}{c}\text { Waste } \\
\text { plastic } \\
\text { (mixture } \\
\text { HDPE+PP) }\end{array}$ & $\begin{array}{c}\text { Sterilised } \\
\text { hospital } \\
\text { waste }\end{array}$ & $\begin{array}{l}\text { Waste } \\
\text { plastic } \\
\text { (mixture } \\
\text { PE+PP) }\end{array}$ & $\begin{array}{l}\text { Waste } \\
\text { tyres }\end{array}$ \\
\hline
\end{tabular}

class $\mathrm{C}$ with a total sulfur content above $1 \mathrm{wt} \%)$, while restrictions on the use of class $B$ and class $C$ fuels are in full compliance with the general restrictions on fuels within the meaning of $\S 6$ of Decree No 228/2014 and Decree No $410 / 2012$.

The restrictions are as follows (Decree No 228/2014) (Ministry of the environment of the Slovak Republic, 2014):

- Class A - according to Decree No 410/2012, annex 4, sections III.5.1.2, IV.4.1.2 and V.5.1.2, it is possible to combust only gaseous fuels and liquid fuels with a sulfur content $\leq 0.1 \mathrm{wt} \%$ in stationary combustion engines;

- Class B - for other medium and large combustion plants (other than gas turbines and piston combustion engines), according to Decree No 410/2012, annex 4, sections IV.2.1.3 and V.2.1.2., the restriction is a maximum sulfur content of $1 \mathrm{wt} \%$;

- Class C - according to Decree No 228/2014, the threshold value of $1 \mathrm{wt} \%$ for the parameter Total Sulfur Content may only be exceeded in the case of heavy fuel oil and marine fuels.

It is evident from Table 4 that in terms of compliance with the established threshold value, pyrolysis facilities processing waste tyres and waste rubber for the production of liquid secondary fuel are problematic, as due to the high sulfur content of the input materials, a high sulfur content of the untreated liquid product is also natural.

Due to the fact that liquid secondary fuels produced in pyrolysis plants in the Slovak Republic are used nearly exclusively for combustion in cogeneration units (i.e. piston combustion engines), the energy utilisation of fuels from the production of waste tyres and rubber on the Slovak market, without the application of a suitable cleaning method, is practically impossible.

\subsection{Testing ability of selected pyrolysis facility to reach $\mathrm{Cl}$ threshold value with real mixed RDF waste}

In order to evaluate the ability of a selected pyrolysis device to reach threshold value for the $\mathrm{Cl}$ content in the gaseous fraction, two types of waste were tested in this facility. During the first test (in April 2017), SRF with very low $\mathrm{Cl}$ content was tested. During the second test, RDF waste was tested. With its composition-particularly the relatively high $\mathrm{Cl}$ content-this waste approached the real, low quality output of the municipal waste sorting process.

The pyrolysis facility WP 05k-TD-G, which was subjected to sampling and analysis during the test operation, consists of the following main parts:

- Feeder;

WP200 TD-H (1st stage of thermal decomposition);

- Evaporation and neutralisation unit for 1st stage,

- WP 200 TD-M (2nd stage of thermal decomposition);

WP 1000 CDF-G (cracking and distillation unit);

Purification unit for main gas fraction (unit underwent slight retrofitting between first and second run);

- Storage tanks for the gaseous fraction;

Storage tanks for the liquid fraction.

The 1 st stage involves, at temperatures up to $300^{\circ} \mathrm{C}$, 
water vapor removal and partial dehalogenation of the feed material. In the 2 nd stage (at temperature range 520 $570^{\circ} \mathrm{C}$ ), the main part of the depolymerization process takes place. The main part of the gas purification unit is an alkaline countercurrent absorber, constructed as a packed-bed scrubber. The absorber uses $25 \% \mathrm{NaOH}$ solution and its dosing is automatically controlled according to the $\mathrm{pH}$ value of the solution. The spent scrubbing solution containing precipitated $\mathrm{NaCl}$ is treated as hazardous waste and replaced in regular intervals (as needed). Due to its properties, it must be disposed of in a hazardous waste landfill.

During the first experimental run, the incoming waste registered with the catalogue number 191210 (waste complying with the normative requirements for SRF). Regarding its origin, it was a high-quality residue from the municipal waste separation process. A total of $50 \mathrm{~kg}$ of this waste was processed at the testing facility, during experimental run, with total operating time of 8 hours (time measured from the beginning of the batching to the end of the final cleaning operation and final disposal of solid residue from reactor).

The following sampling was performed during this operation:

- Sampling of the gaseous fraction from the sampling point at the outlet of the alkaline absorber. Only total $\mathrm{Cl}$ were determined in the sample.

During the second experimental run, the incoming waste registered with the catalogue number 191210 (waste complying with the lower classes of normative requirements - also referred to as RDF waste). Regarding its origin, it was a flammable residue from the municipal waste separation process.

A total of $45 \mathrm{~kg}$ of this waste was processed at the testing facility, during experimental run, with total operating time of 7 hours (time measured from the beginning of the batching to the end of the final cleaning operation and final disposal of solid residue from reactor).

The following sampling was performed during this operation:

- Sampling of the gaseous fraction from the sampling point between the first stage of the reactor section and the evaporation and neutralization unit. Total $\mathrm{Cl}$, organic $\mathrm{Cl}$ and inorganic $\mathrm{Cl}$ were determined in the sample;

- Sampling of the gaseous fraction from the sampling point between the Cracking and the distillation unit and the alkaline absorber. total $\mathrm{Cl}$, organic $\mathrm{Cl}$ and inorganic $\mathrm{Cl}$ were determined in the sample;

- Sampling of the gaseous fraction from the sampling point at the outlet of the alkaline absorber. Total $\mathrm{Cl}$, organic $\mathrm{Cl}$ and inorganic $\mathrm{Cl}$ were determined in the sample.

Sampling of the pyrolysis gas for the determination of Cl was carried out using Tedlar gas sampling bags with capacities of 1 litre and 10 litres. These bags were repeatedly helium-purified and then vacuumed before use. The sampling was carried out by overpressure, by direct filling of the bag. The individual parameters were determined according to the methodologies defined in the technical standards as follows:

- Chlorine compounds expressed as HCl: STN EN 1457/ STN EN 14582 (Characterization of waste. Halogen and sulfur content. Oxygen combustion in closed systems and determination methods);

- Total Cl - STN EN 1458/ STN EN 14582 (Characterization of waste. Halogen and sulfur content. Oxygen combustion in closed systems and determination methods);

- Sum of $\mathrm{Cl}$ in its organochlorine compounds - computation.

In both cases, analysis of input waste was also made, including total $\mathrm{Cl}$ content.

\subsubsection{Results of experimental runs}

The relevant results of first testing run are given in Table 6 .

The primary reason for this testing was to attempt to reach the threshold value for the $\mathrm{Cl}$ content in the gas fraction. However, the first test made it clear that achieving this value by using waste with a composition close to that of real mixed municipal waste (and therefore containing high amount of $\mathrm{Cl}$ in the form of PVC) would be far from straightforward.

The first run results clearly identified the following problems:

- $\mathrm{Cl}$ content in the gaseous fraction, using waste containing 0.05 wt.\% of $\mathrm{Cl}$, exceeds the existing threshold value for $\mathrm{Cl}$ content by two orders of magnitude;

- As the overall ability of the purifying unit (designed as an alkaline wet scrubber) to reduce this value to the required level is conditional on the presence of exclusively the inorganic form of $\mathrm{Cl}$ in the purified gas, any significant presence of the organic form of $\mathrm{Cl}$ in this gas is a substantial obstacle to achieving the threshold value for $\mathrm{Cl}$;

- Since only total $\mathrm{Cl}$ (organic and inorganic) was determined in the sample, it was not possible to determine, on the basis of the first test run, whether the alkaline wet scrubber method is sufficient.

Based on these problems, a second experimental run was prepared and conducted to resolve these issues. In addition to the fact that both organic and inorganic $\mathrm{Cl}$ were measured, pyrolysis equipment was retrofitted with a new, more efficient version of the alkaline wet scrubber, and mixed waste residue with relatively low quality (and thus with high $\mathrm{Cl}$ content) was used as input waste. The relevant results of the second testing run are given in Table 7.

As can be seen from these results, total $\mathrm{Cl}$ content in the gaseous fraction, using waste containing $0.4 \mathrm{wt}$.\% of $\mathrm{Cl}$, exceeds the existing threshold value for $\mathrm{Cl}$ content by three orders of magnitude (and this increase in total $\mathrm{Cl}$ content in gas fraction is roughly equivalent to the increase of total $\mathrm{Cl}$ content in input waste). A substantial part (up to $99 \%$ ) of 
TABLE 6: Relevant results of first testing run.

\begin{tabular}{|c|c|}
\hline Parameter & Pollutant content ${ }^{1)}$ \\
\hline total $\mathrm{Cl}$ in input waste & $0.053 w t \%$ \\
\hline Legal threshold for total $\mathrm{Cl}$ in gaseous fraction & $1 \mathrm{mg} \cdot \mathrm{m}_{\mathrm{n}}^{-3}$ \\
\hline $\begin{array}{l}\text { total } \mathrm{Cl} \text { in gaseous fraction at the output of } \\
\text { gas purification unit }\end{array}$ & $342.19 \mathrm{mg} \cdot \mathrm{m}_{\mathrm{n}}^{-31)}$ \\
\hline
\end{tabular}

1) Standard state conditions: temperature $0^{\circ} \mathrm{C}$, pressure $101.3 \mathrm{kPa}$

TABLE 7: Relevant results of second testing run

\begin{tabular}{|c|c|}
\hline Parameter & Pollutant content ${ }^{1)}$ \\
\hline total $\mathrm{Cl}$ in input waste & $0.4 w t \%$ \\
\hline Legal threshold for total $\mathrm{Cl}$ in gaseous fraction & $1 \mathrm{mg} \cdot \mathrm{m}_{\mathrm{n}}^{-3}$ \\
\hline $\begin{array}{l}\text { total } \mathrm{Cl} \text { in gaseous fraction at the output from } \\
\text { the } 1 \text { st stage of reactor unit }\end{array}$ & $7,574 \mathrm{mg} \cdot \mathrm{m}_{\mathrm{n}}^{-31)}$ \\
\hline $\begin{array}{l}\text { organic } \mathrm{Cl} \text { in gaseous fraction at the output } \\
\text { from the } 1 \text { st stage of reactor unit }\end{array}$ & $7,573 \mathrm{mg} \cdot \mathrm{m}_{\mathrm{n}}^{-31)}$ \\
\hline $\begin{array}{l}\text { total } \mathrm{Cl} \text { in gaseous fraction at the input of gas } \\
\text { purification unit }\end{array}$ & $6,779.38 m g \cdot m_{n}^{-31)}$ \\
\hline $\begin{array}{l}\text { organic } \mathrm{Cl} \text { in gaseous fraction at the input of } \\
\text { gas purification unit }\end{array}$ & $6,778.00 \mathrm{mg} \cdot \mathrm{m}_{\mathrm{n}}^{-31)}$ \\
\hline $\begin{array}{l}\text { total } \mathrm{Cl} \text { in gaseous fraction at the output of gas } \\
\text { purification unit }\end{array}$ & $5,527.84 m g \cdot m_{n}^{-31)}$ \\
\hline $\begin{array}{l}\text { organic } \mathrm{Cl} \text { in gaseous fraction at the output of } \\
\text { gas purification unit }\end{array}$ & $5,526.00 \mathrm{mg} \mathrm{m}_{\mathrm{n}}^{-31)}$ \\
\hline
\end{tabular}

1) Standard state conditions: temperature $0^{\circ} \mathrm{C}$, pressure $101.3 \mathrm{kPa}$

the $\mathrm{Cl}$ in the gaseous fraction is actually present in organic form.

According to the standard model of thermal decomposition of PVC (as the main source of $\mathrm{Cl}$ in waste), as indicated by several studies, pyrolytic decomposition of PVC is a two-stage process in which the dechlorination itself, together with formation of some hydrocarbon compounds such as benzene, naphthalene and anthracene, takes place mainly in the first stage (up to $360^{\circ} \mathrm{C}$ ). In the second step, the primary polyene chain exposed in the first stage is then cleaved [6-9].

The reason for this two-step reaction scheme is that the $\mathrm{C}-\mathrm{Cl}$ binding energy (in the PVC structure) is significantly lower than the binding energies of $\mathrm{C}-\mathrm{C}$ and $\mathrm{C}-\mathrm{H}$ bonds (Castro, Soares, Vilarinho, \& Castro, 2012)the presence of poly(vinyl chloride.

The formation of $\mathrm{HCl}$ in this process is a radical reaction, which can be expressed as follows:

$$
-\left(\mathrm{CH}_{2}-\mathrm{CHCl}\right)_{n}-\rightarrow-(\mathrm{CH}=\mathrm{CH})_{n}-+n \mathrm{HCl}
$$

$\mathrm{HCl}$ begins to release in detectable amounts at temperatures of $240^{\circ} \mathrm{C}$ and this process reaches its maximum at temperatures of about $300-310^{\circ} \mathrm{C}$.

The study indicates that the dechlorination process itself is in fact a system of two parallel reactions in which, apart from $\mathrm{HCl}$ itself, certain amounts of volatile hydrocarbon compounds are also produced (Castro et al., 2012)the presence of poly(vinyl chloride.

In a similar way, the study of Marcilla and Beltran (1995) (Marcilla \& Beltran, 1995), using thermogravimetric analysis of PVC pyrolysis, concluded that the first stage of pyrolysis decomposition of PVC, in which dechlorination occurs and some of the volatile organic compounds are formed, can only be accurately explained using a model contemplating two parallel reactions.

Another study (Montaudo \& Puglisi, 1991), using mass spectrometry, also showed the presence of two parallel processes in the first stage of thermal decomposition of PVC. The authors of this study explain this by the thermal decomposition of PVC beginning with the release of $\mathrm{HCl}$ (according to a known and generally accepted mechanism) and as soon as the release of the main polyene chain is initiated, a second parallel process is initiated in which a small amount of unsubstituted aromatic constituents is released (benzene, naphthalene, anthracene).

However, the fact that in our case $\mathrm{Cl}$ in the gas phase occurs practically exclusively in organic form (as opposed to the model assuming as the main form of degradation the formation of $\mathrm{HCl}$ molecules) indicates other, possibly unknown significant mechanisms occurring either directly in the thermal decomposition process, or subsequently in the pyrolysis gas that is formed. The main result of this mechanism is the formation of a wide spectrum of chloroorganic molecules.

The most important result of this experimental part is the fact that if such a high concentration of organic $\mathrm{Cl}$ in the pyrolysis gas (when processing RDF waste of low quality and high $\mathrm{Cl}$ content) is also confirmed by analysis on other similar pyrolysis facilities, there are virtually no real, technically and economically feasible possibilities of purifying such a gaseous fraction in order to achieve an extremely low threshold value for $\mathrm{Cl}$ content.

It is also important to note that none of the available analyses listed in Table 4 carried out on other ATT facilities evaluated the distribution of $\mathrm{Cl}$ in the gas phase between the organic and inorganic components (all of these cases referred exclusively to total $\mathrm{Cl}$ values).

Another important fact is that in the case of the pyrolysis treatment of medical waste with a total $\mathrm{Cl}$ content in the input waste even higher than during our second experiment ( $0.6 \%$ wt., see Table 4$)$, the total amount of $\mathrm{Cl}$ was shown to be lower in the gaseous fraction than in our case tested (despite the fact that the facility in question, labelled as Facility 4 in Table 4, did not have any gas cleaning device).

Based on these problems, the most important part of our further research is to clarify whether such high concentrations of total (including organic) $\mathrm{Cl}$ in the gaseous phase are attributed only to this testing facility or whether such concentrations and, most importantly, the distribution between organic and inorganic $\mathrm{Cl}$, will also be confirmed at other facilities of a similar type.

In the event this high concentration of organic $\mathrm{Cl}$ in the pyrolysis gas is confirmed, the only remaining possibilities are:

- the development of a new, advanced method of purifying a high $\mathrm{Cl}$ content in pyrolysis gas in organic form (at significant cost and technical difficulty), or

- operation of pyrolysis facilities in waste incineration mode according to the second possibility indicated in the first part of this paper (Current legislative fra- 
mework - The importance of threshold values) as follows: the facility produces "fuel" that does not attain end-of-waste parameters. Such an output "product" remains waste and its subsequent use in combustion plants is subject to the same requirements as to waste incinerators.

\section{CONCLUSIONS AND THE FURTHER RESE- $\mathrm{ARCH}$}

At the present time, any projects for the energy recovery of waste in classic incinerators, as probably the most environmentally and economically efficient ways of energy recovery, are close to impossible in the Slovak Republic because of massive public opposition. Therefore, it is legitimate to consider projects based on alternative thermal methods for the processing of wastes (pyrolysis and gasification) as a potentially interesting and important part of the waste management hierarchy if such facilities would solve the most important environmental issues analysed in this paper.

This paper provides an overview of the key environmental requirements related to alternative thermal facilities for the processing of wastes (pyrolysis and gasification) that provide the specific threshold values for the individual pollutants contained in the gaseous and liquid fraction produced at the output of these facilities.

One of the main findings of this paper is the identification of

- inadequately proposed threshold value for liquid secondary fuels from waste,

undefined threshold values for gaseous secondary fuels from waste

and the follow-up proposal of new threshold values for these problematic ones. The new proposed values are based on simple analogy with Austrian ordinance no. 389/2002(Bundesministers für Land- und Forstwirtschaft, Umwelt und Wasserwirtschaft und des Bundesministers für Wirtschaft, 2002) and the underlying standard ÖVGW Richtline G 31 "Natural gas in Austria" (for "Particles/Aerosols") and with the existing Slovak Decree No 410/2012 for flue gas from waste incinerators (for "Other metals and their compounds" and "POPs").

Another key finding is the confirmation of a high content of chloro-organic compounds in pyrolysis gas produced from RDF waste with equally high $\mathrm{Cl}$ content. The fact that such compounds are practically impossible to remove from gas by use of an alkaline wet scrubber or any other standard cleaning method is a significant obstacle to achieving purity of pyrolysis gas at the level of secondary fuel.

Should such distribution of total $\mathrm{Cl}$ between the organic and inorganic forms, along with such concentrations of chloro-organic compounds, be confirmed at other ATT facilities of a similar type (using low-grade mixed waste with high levels of $\mathrm{Cl}$ ), it will mean that the operator of such a facility will have to choose one of the following options:

- Technically difficult and costly development of new, advanced method of purifying pyrolysis gas with high $\mathrm{Cl}$ content in organic form,

- Operation of pyrolysis facilities in waste incineration mode (incineration mode will apply exclusively to combustion of the gaseous fraction).

- It follows that the most important part of our further research is to clarify whether such high concentrations of total (including organic) $\mathrm{Cl}$ in the gaseous phase are attributed only to this testing facility or whether such concentrations and, most importantly, the distribution between organic and inorganic $\mathrm{Cl}$ will also be confirmed at other facilities of a similar type.

\section{ACKNOWLEDGEMENTS}

This paper was supported by the Slovak Grant Agency KEGA under Contract No 030UMB-4/2017 "Educational Centre for Integrated Safety".

\section{REFERENCES}

Bundesministers für Land- und Forstwirtschaft, Umwelt und Wasserwirtschaft und des Bundesministers für Wirtschaft, F. und J. Verordnung des Bundesministers für Land- und Forstwirtschaft, Umwelt und Wasserwirtschaft und des Bundesministers für Wirtschaft, Familie und Jugend über die Verbrennung von Abfällen (2002). Bundesministers für Land- und Forstwirtschaft, Umwelt und Wasserwirtschaft und des Bundesministers für Wirtschaft, Familie und Jugend.

Castro, A., Soares, D., Vilarinho, C., \& Castro, F. (2012). Kinetics of thermal de-chlorination of PVC under pyrolytic conditions. Waste Management, 32(5), 847-851. https://doi.org/10.1016/j.wasman.2012.01.004

Hroncová, E., Ladomerský, J., \& Musil, J. (2016). Problematic issues of atmosphere protection during thermal processes related to the energetic uses of waste. In Proceedings Venice2016, Sixth International Symposium on Energy from Biomass and Waste, 14 - 17 November 2016 (pp. 14-17).

Kim, S. (2001). Pyrolysis kinetics of waste PVC pipe. Waste Management, 21(7), 609-616. https://doi.org/10.1016/S0956053X(00)00127-6

Marcilla, A., \& Beltran, M. (1995). Thermogravimetric kinetic study of poly(vinylchloride) pyrolysis. Polymer Degradation and Stability, 3910(95), 219-229.

Ministry of the environment of the Slovak Republic. Decree no. $228 / 2017$ coll. stating the requirements for the quality of fuel and the maintenance of fuel operation records (2014). Ministry of the environment of the Slovak Republic.

Montaudo, G., \& Puglisi, C. (1991). Evolution of aromatics in the thermal degradation of poly(vinyl chloride): A mechanistic study. Polymer Degradation and Stability, 33(2), 229-262. https://doi. org/10.1016/0141-3910(91)90019-N

Quicker, P., Neuerburg, F., Noël, Y., \& Huras, A. (2015). Status of Alternative Techniques for Thermal Waste Treatment - Final Report. Aachen. 